\title{
Evidence That Fibroblast Growth Factor 5 Is a Major Muscle-Derived Survival Factor for Cultured Spinal Motoneurons
}

\author{
Richard A. Hughes, * Michael Sendtner, * \\ Mitchell Goldfarb, ${ }^{\dagger}$ Dan Lindholm, ${ }^{*}$ \\ and Hans Thoenen* \\ *Department of Neurochemistry \\ Max-Planck-Institute for Psychiatry \\ 8033 Planegg-Martinsried \\ Germany \\ tDepartment of Biochemistry \\ and Molecular Biophysics \\ College of Physicians and Surgeons \\ Columbia University \\ New York, New York 10032
}

\section{Summary}

We examined the potential role of fibroblast growth factor 5 (FGF-5) as a target-derived trophic factor for spinal motoneurons. Northern analysis of total RNA from rat skeletal muscle revealed an FGF-5 mRNA transcript both during the period of embryonic motoneuron death and in the adult. Recombinant human FGF-5 supported the survival of highly enriched cultures of embryonic chick motoneurons. Significant proportions of the motoneuron survival activity of rat skeletal muscle extracts could be immunoprecipitated using an antiserum to FGF-5. The immunoprecipitable activity was present in soluble and matrix-bound forms in embryonic muscle, but bound exclusively to the extracellular matrix in adult muscle. These results, along with the secretory nature of FGF-5, suggest that FGF-5 may act as a target-derived trophic factor for motoneurons.

\section{Introduction}

During the course of embryonic development, many neuronal populations undergo a period of naturally occurring cell death. In the vertebrate, the survival of neurons during this period has been demonstrated in several instances to be dependent upon access of the developing neurons to specific trophic factors supplied by target tissues (for review, see Oppenheim, 1991). For example, nerve growth factor (NGF) is known to be produced in limiting amounts in the target tissues of peripheral sympathetic and sensory neurons, and considerable evidence has been accumulated demonstrating that NGF supports the survival of these cells during critical stages of development (for review, see Barde, 1989). Similarly, motoneurons have been shown to rely upon their target during the embryonic period of naturally occurring cell death (Hamburger, 1958; Hollyday and Hamburger, 1976). In addition, a number of groups have described the ability of extracts of skeletal muscle, the target of motoneurons, to promote the survival of motoneurons in culture (Bennett et al., 1980; Schnaar and Schaffner, 1981; Calof and Reichardt, 1984; Kaufman et al., 1985;
Flanigan et al., 1985; Smith et al., 1985; Dohrmann et al., 1986; O'Brien and Fischbach, 1986; Martinou et al., 1989; Arakawa et al., 1990; Bloch-Gallego et al., 1991; Jeong et al., 1991). However, attempts to determine the molecular nature of the factor(s) involved in regulating motoneuron survival during development have been largely unfruitful.

We have previously demonstrated that several neurotrophic and growth factors support the survival of spinal motoneurons in highly enriched cultures taken from embryonic day 6 (E6) chick (Arakawa et al., 1990). The best of these, ciliary neurotrophic factor (CNTF) and basic fibroblast growth factor (bFGF), support the survival of approximately $60 \%$ and $50 \%$, respectively, of the initially plated motoneurons after 3 days in culture. In combination, CNTF and bFGF give $100 \%$ motoneuron survival under the in vitro conditions employed. Furthermore, exogenously applied recombinant CNTF is able to prevent the otherwise extensive motoneuron degeneration seen after lesion of the facial nerve of the newborn rat (Sendtner et al., 1990) as well as rescue a significant number of spinal motoneurons that would otherwise undergo naturally occurring cell death in the embryonic chick (Oppenheim et al., 1991). However, neither CNTF nor bFCF is likely to be responsible for the physiological regulation of embryonic neuronal survival, since both CNTF and bFGF are apparently cytosolic molecules (Abraham et al., 1986; Lin et al., 1989; Stöckli et al., 1989) and CNTF mRNA cannot be detected in skeletal muscle during the period of embryonic motoneuron death in the rat (Stöckli et al., 1991).

To meet the requirements expected of a neurotrophic factor capable of regulating motoneuron survival during the embryonic period of cell death, a putative candidate molecule should support motoneuron survival and be appropriately expressed in target tissues. We have examined a member of the FGF family, FGF-5, for its ability to fulfill these criteria. FGF-5 was originally described as the product of a human oncogene (Zhan et al., 1987) and upon cloning was found to belong to the FGF family (Zhan et al., 1988). FGF-5 consists of 268 amino acids and appears to be moderately well conserved across mammals; the murine homolog shows $84 \%$ overall amino acid identity with the human form (Hébert et al., 1990). Unlike the prototypical FGFs, acidic FGF (aFGF) and bFGF. FGF-5 contains a hydrophobic N-terminal leader sequence typical of a secreted protein (Zhan et al., 1988) and is released into the medium of transformed NIH 3T3 cells (Bates et al., 1991). mRNA for FGF-5 can be found prior to gastrulation in mouse embryos, suggesting that this factor may have an important function during very early stages of embryonic development (Hébert et al., 1991; Haub and Goldfarb, 1991). We demonstrate here that recombinant human FGF-5 is able to support the survival of chick 
spinal motoneurons in culture and that both FCF-5 mRNA and immunoprecipitable activity are present in embryonic rat skeletal muscle during the period of naturally occurring motoneuron death as well as in adult muscle. The data indicate that FGF-5 is a major survival factor present in skeletal muscle for cultured spinal motoneurons and, taken together with the secretory nature of FGF-5, are consistent with a potential role for this protein in the maintenance of motoneuron survival during development and adulthood.

\section{Results}

\section{The mRNA for FGF-5 Is Expressed in Rat Skeletal Muscle during Embryonic Development and in the Adult}

To determine whether FGF-5 mRNA is expressed in the target tissue of motoneurons either during embryonic development or in adulthood, we performed Northern blot analysis of total RNA obtained from hindlimb skeletal muscle of embryonic (E15 and E17), newborn, and adult rats. Following high stringency washing, a cRNA probe from mouse FGF- 5 was found to hybridize specifically to a band migrating marginally faster than the $18 \mathrm{~S}$ band (approximately $1.7 \mathrm{~kb}$ ) in rat skeletal muscle RNA at all time points studied (Figure 1a). The FGF-5-specific transcript observed in muscle is similar in size to the major FGF- 5 transcript seen in Northern blots of polyadenylated RNA obtained from cultured human fibroblasts (Werner et al., 1991). The probe also hybridizes to a band of identical size in adult rat hippocampus (Figure 1b), a known site of FGF-5 expression in the mouse (Haub et al., 1990).

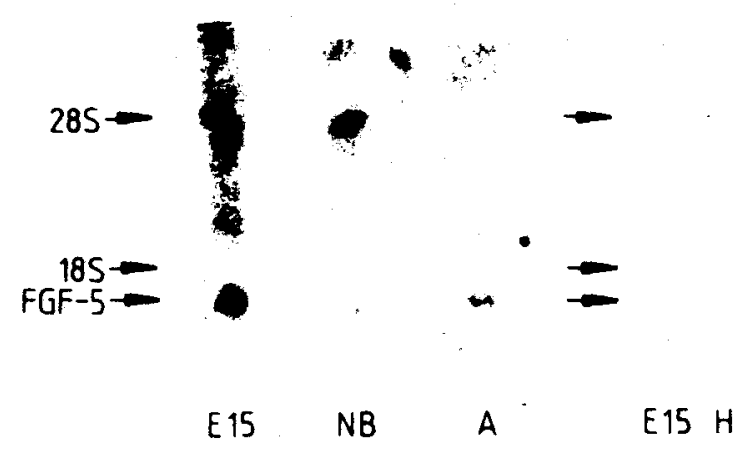

Figure 1. Northern Blots Hybridized with a 500 bp cRNA Probe to FGF-5

(a) Total RNA (16 $\mu \mathrm{g}$ ) from embryonic (E15 and E17), newborn (NB), and adult (A) rat skeletal muscle. Blot were exposed for 7 days.

(b) Comparison of size of FGF-5 transcript in $5 \mu \mathrm{g}$ of total RNA obtained from E15 rat skeletal muscle (E15) and adult rat hippocampus $(H)$. Blots were exposed for 3 days. The positions of the FCF-5-specific message and of the 185 and 285 ribosomal RNA bands are indicated by arrows.

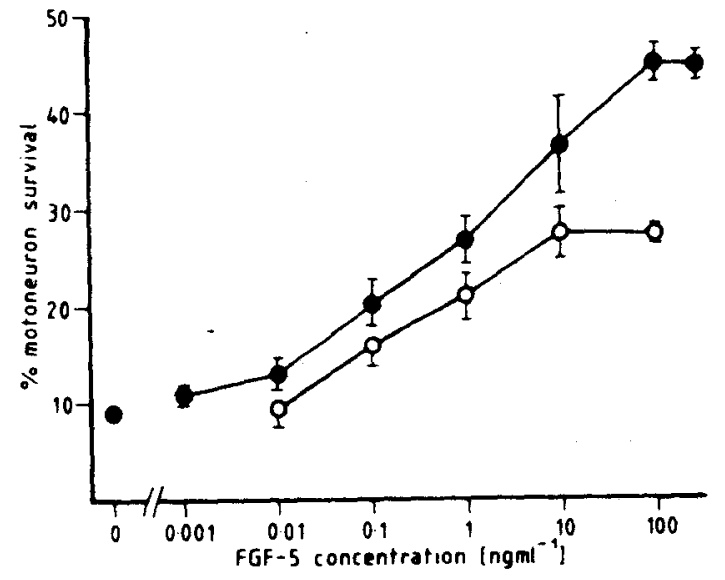

Figure 2. Effects of Increasing Concentration of Recombinant Human FGF-5 on Survival of Cultured E6 Chick Motoneurons in the Absence and Presence of Heparin

Results are means \pm 1 standard deviation from a minimum of tour cultures from at least two independent experiments. Open circles, no added heparin; closed circles, $500 \mathrm{ng} / \mathrm{ml}$ heparin.

\section{FGF-5 Supports the Survival of E6 Chick Spinal Motoneurons in Culture}

The ability of recombinant human FCF-5 to support the survival of $\mathrm{E} 6$ chick motoneurons in vitro was determined in the absence and presence of heparin (Figure 2). Alone, FGF-5 supports the survival of a maximum of $27 \%$ of the initially plated motoneurons at a concentration of $10 \mathrm{ng} / \mathrm{ml}$ after $72 \mathrm{hr}$ in culture. In the presence of heparin sulphate $(500 \mathrm{ng} / \mathrm{ml})$, the survival effect of FGF- 5 is increased significantly, such that $45 \%$ of plated motoneurons are supported at a concentration of $100 \mathrm{ng} / \mathrm{ml}$. Motoneurons cultured in the presence of the same concentration of heparin alone did not exhibit significantly better survival behavior than control cultures ( $9 \%$ survival after 3 days). The concentration of FCF- 5 required to give half-maximal survival of motoneurons is $800 \mathrm{pg} / \mathrm{ml}$. Thus, in cultures of $\mathrm{E} 6$ chick spinal motoneurons, FGF-5 is less effective in promoting neuronal survival than either bFGF or CNTF (maximally $50 \%$ and $61 \%$ survival, respectively. after 3 days in culture), but significantly better than other heparin-dependent members of the FGF family tested, such as aFGF and $h s t / \mathrm{K}-\mathrm{FGF}$ (maximally $36 \%$ and $32 \%$ survival, respectively, after 3 days in culture; Figure 3). Furthermore, combination of FGF-5 with either CNTF or bFGF at supramaximal concentrations in the presence of heparin $(500 \mathrm{ng} / \mathrm{ml})$ gave an additive effect on motoneuron survival, such that FGF-5 and CNTF or FGF-5 and bFCF supported approximately $74 \%$ and $80 \%$, respectively, of the originally plated motoneurons after 3 days in culture (Figure 3). Similarly to CNTF and bFGF, FGF-5 supported the survival of cultured E8 chick ciliary ganglion neurons (data not shown). 


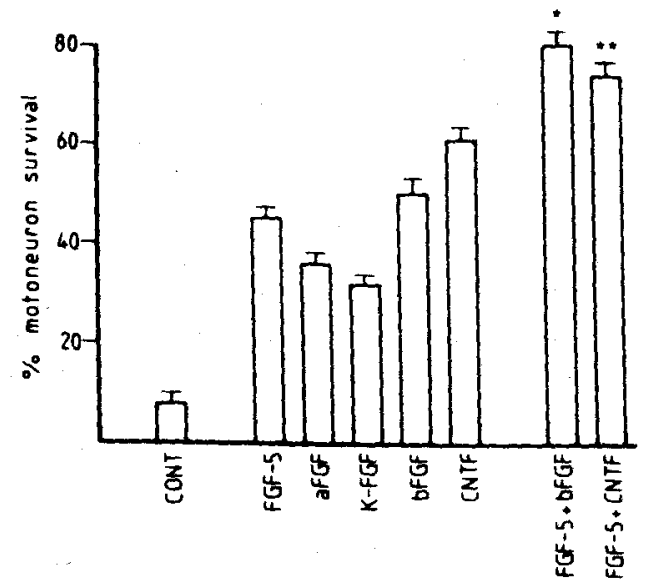

Figure 3. Comparison of Maximum Motoneuron Survival Activity and Synergism of FGF-5 with CNTF and Other Members of the FGF Family

Factors were added to cultures in concentrations previously determined as exhibiting maximal survival effects: FGF-5, aFGF, and hst $/ \mathrm{K}-F G F$ at $100 \mathrm{ng} / \mathrm{ml}$; bFGF at $20 \mathrm{ng} / \mathrm{ml}$; CNTF at $1 \mathrm{ng} / \mathrm{ml}$. Results are means from six determinations from three independent experiments. Error bars represent 1 SEM. Statistical significance was established with Student's t test: * Survival significantly ditferent from cultures containing bFGF alone, $P<0.00005$. * Survival significantly different from CNTF alone, $P<0.005$.

\section{A Significant Proportion of the Survival Activity of Extracts of Embryonic Skeletal Muscle Can Be Precipitated with an Anti-FGF-5 Peptide Antiserum} To investigate the contribution, if any, of FGF-5 to the motoneuron survival activity of embryonic and adult rat skeletal muscle extracts, we performed immunoprecipitation experiments with an antiserum to FGF-5. The antiserum was raised in rabbits against a synthetic peptide representing a sequence from near the C-terminus of human FGF-5. The sequence was judged by hydropathy analysis (Hopp and Woods, 1981; Kyte and Doolittle, 1982) to be relatively hydrophilic and therefore likely to be exposed on the surface of intact FGF-5. Furthermore, the peptide spans a region of the C-terminal "tail" of FGF-5, which, although well conserved between species, is not present in the other known members of the FGF family; this fact reduces the likelihood that the resultant antiserum would cross-react with other FGFs. Although the antiserum raised against this peptide did not recognize recombinant human FGF-5 on immunoblots (data not shown), it was possible to precipitate the motoneuron survival activity of recombinant human FGF-5 almost entirely using the antiserum (Figure 4), consistent with an ability of this antiserum to recognize native FGF-5 in solution. In contrast, the antiserum was unable to immunoprecipitate the motoneuron survival activity of either any other member of the FGF family tested (aFGF, bFGF, and hst/K-FGF) or CNTF.

Figure 5 shows the motoneuron survival activity of an extract of phosphate-buffered saline (PBS)-soluble components of $\mathrm{E} 17$ rat skeletal muscle before (column
B) and after (column C) the addition of anti-FGF-5 antiserum bound to protein G-Sepharose. Following centrifugation of the antiserum-Sepharose complex, the survival activity of the soluble embryonic muscle extract on E6 chick spinal motoneurons at the maximum protein concentration tested $(250 \mu \mathrm{g} / \mathrm{ml})$ was reduced from $60 \%$ to $36 \%$ after 3 days in culture. This represents a $47 \%$ reduction in survival activity, given the background survival of $9 \%$ in control cultures (Figure 5, column A). The result suggests that a significant proportion of the survival activity of the PBS-soluble components of $\mathrm{E} 17$ rat skeletal muscle may be due to FGF-5.

Members of the FGF family, including FGF-5, have a propensity to bind to components of the extracellular matrix. We thus attempted to determine whether additional, matrix-bound, FGF-5-like motoneuron survival activity that could not be extracted with PBS alone is present in embryonic rat skeletal muscle. The pellets obtained after PBS extraction of E17 muscle were reextracted with PBS containing $3 \mathrm{M} \mathrm{NaCl}$ and $10 \mathrm{mM}$ EDTA. These conditions would be expected to disrupt interactions between the extracellular matrix and molecules bound to it and thus allow solubilization of matrix-bound components. The high molar salt extract of E17 muscle exhibited a maximal survival effect on cultured chick spinal motoneurons which was less than that observed with the soluble extract (approximately $37 \%$ survival after 3 days in culture; Figure 5, column E), although this effect was achieved at lower total protein concentrations $(60 \mu \mathrm{g} / \mathrm{ml})$. $1 \mathrm{~m}$ munoprecipitation of this extract with anti-FGF-5 antiserum led to an $83 \%$ reduction in the maximal motoneuron survival of the extract (figure 5, column F).

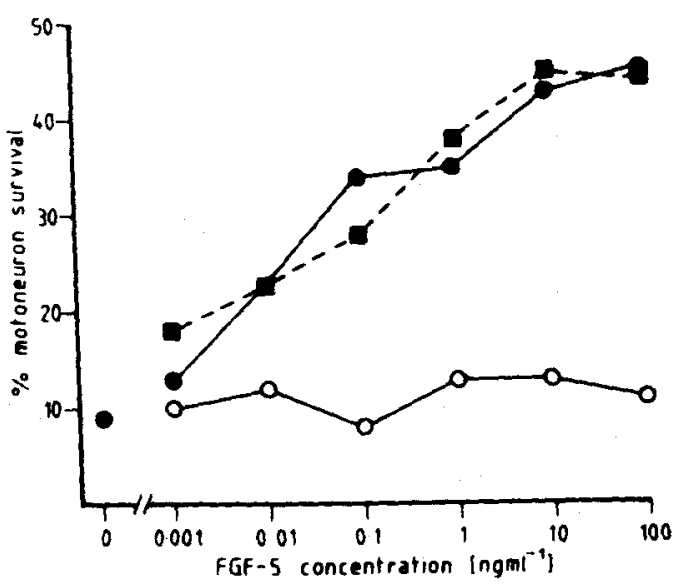

Figure 4. Motoneuron Survival Activity of Increasing Concentrations of Recombinant Human FGF-5 Prior to or Following Immunoprecipitation with Either Anti-FGF-5 or Control Anti-CNTF Antiserum

Closed circles, survival prior to immunoprecipitation; open circles, survival following immunoprecipitation with anti-FGF-5 antibodies; squares, survival following immunoprecipitation with anti-CNTF antibodies. 


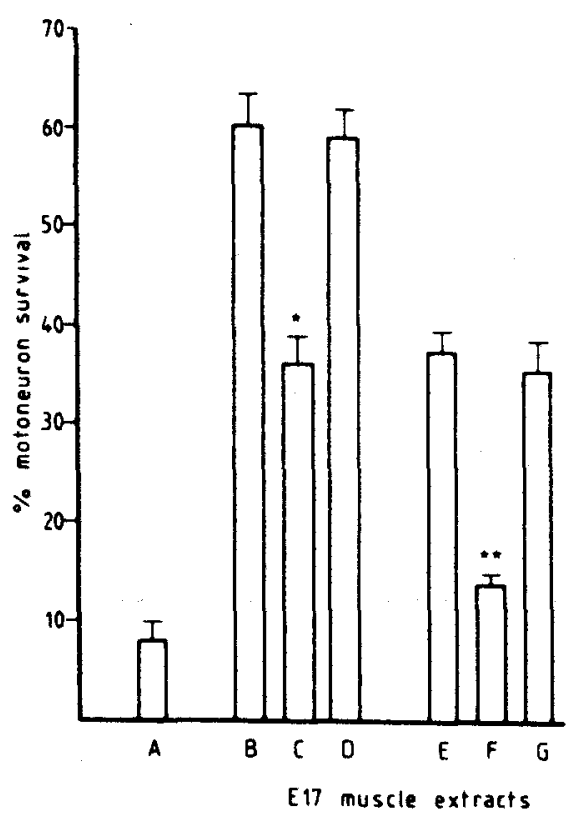

Figure 5. Motoneuron Survival Activity of E17 Muscle Extracts Column A: Control, no muscle extract. Columns B-D: Addition of $250 \mu \mathrm{g} / \mathrm{ml}$ PBS-soluble extract prior to (column B) and following immunoprecipitation with anti-FGF-5 (column C) or antiCNTF (column D) antiserum. Columns E-C: Addition of $70 \mu \mathrm{g} / \mathrm{ml}$ high molar salt-EDTA extract prior to (column E) and following immunoprecipitation with anti-FCF-5 (column F) or anti-CNTF (column G) antiserum. Resuits are means from at least four cultures from at least two independent experiments. Error bars represent 1 SEM. Statistical significance was established with Student's t test: * Significantly different from PBS-soluble extract prior to immunoprecipitation, $\mathrm{P}<0.0005$. * Significantly different from high salt extract prior to immunoprecipitation, $\mathrm{P}<$ 0.00005 .

Thus, approximately $65 \%$ of the total (PBS and high molar salt) maximal motoneuron survival activity extractable from $\mathrm{E} 17$ rat skeletal muscle can be immunoprecipitated by anti-FGF-5 antiserum, and approximately one-half of this activity is apparently quite tightly bound to the matrix. Control precipitation of either the soluble or matrix-bound extract of embryonic muscle with anti-CNTF antiserum did not lead to a significant reduction in the motoneuron survival activity of either of these extracts (Figure 5, columns $D$ and G). Reextraction of the muscle pellets with PBS alone failed to solubilize significant amounts of either total protein or motoneuron survival activity (data not shown).

\section{Immunoprecipitation of Adult Muscle Extracts with Anti-FGF-5 Antiserum Suggests That FGF-5 Protein Is Almost Entirely Matrix Bound}

To determine whether FGF-5 might also be a component of adult rat skeletal muscle extracts, attempts were made to precipitate motoneuron survival activity from adult muscle extracts with anti-FGF-5 antiserum linked to protein G-Sepharose. PBS-soluble extracts of adult skeletal muscle exhibited maximal motoneuron survival activity of approximately $37 \%$ at a protein concentration of $125 \mu \mathrm{g} / \mathrm{ml}$ after 3 days in culture (Figure 6, column B). However, unlike the PBS-soluble embryonic muscle extract, none of the activity of the soluble extract of adult rat skeletal muscle could be precipitated with anti-FGF-5 antiserum (Figure 6, column C). Conversely, a major proportion (71\%) of the maximal survival activity of the high molar salt extract of adult rat skeletal muscle extract $(33 \%$ at $7 \mu \mathrm{g} / \mathrm{ml}$ protein) could be precipitated with anti-FGF- 5 antiserum (Figure 6, columns $E$ and F). The fact that FGF-5 immunoprecipitable activity could not be extracted from adult rat skeletal muscle with PBS and required harsher extraction conditions of high salt and EDTA to facilitate its solubilization, suggests that FGF-5 in adult rat muscle is almost exclusively tightly bound to the extracellular matrix. Small proportions of both the PBS-soluble and high molar salt-EDTA extracts of adult muscle (approximately $30 \%$ and $29 \%$, respectively) were amenable to immunoprecipitation with anti-CNTF antiserum (Figure 6, columns D and G).

\section{Discussion}

The motoneuron survival activity obtainable from embryonic and adult rat skeletal muscle could be broadly divided into two categories: that readily extractable with PBS and that requiring high molar salt and EDTA to effect solubilization. Of the four types of muscle

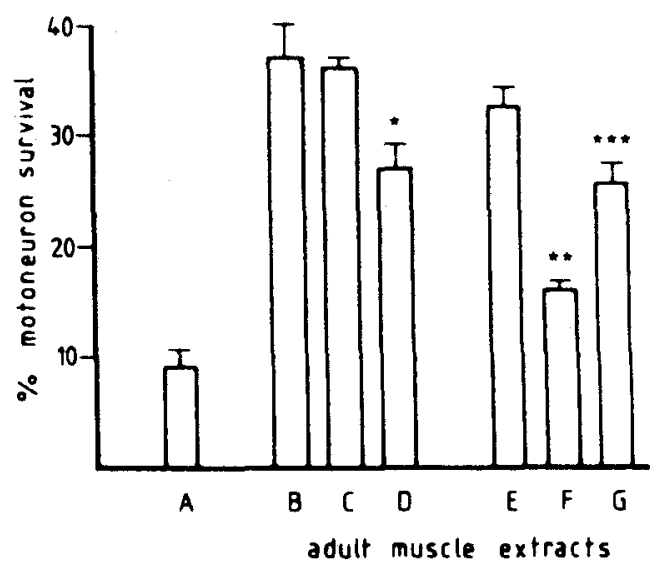

Figure 6. Motoneuron Survival Activity of Adult Muscle Extracts Column A: Control, no muscle extract. Columns B-D: Addition of $125 \mu \mathrm{g} / \mathrm{ml}$ PBS-soluble extract prior to (column B) and following immunoprecipitation with anti-FCF-5 (column C) or antiCNTF (column D) antiserum. Columns E-G: Addition of $7 \mu \mathrm{g} / \mathrm{ml}$ high molar salt-EDTA extract prior to (column E) and following immunoprecipitation with anti-FGF-5 (column F) or anti-CNTF (column G) antiserum. Results are means from four cultures from two experiments. Error bars represent 1 SEM. Statistical significance was established with Student's t test: * Significantly different from PBS-soluble extract prior to immunoprecipitation, $\mathrm{P}<$ $0.05 . *$ Significantly different from high salt extract prior to immunoprecipitation, $\mathrm{P}<0.0005$. *** Significantly different from high salt extract prior to immunoprecipitation, $\mathrm{P}<0.05$. 
extract prepared, the PBS-soluble extract of E17 muscle gave the greatest maximal survival effect on cultured chick motoneurons ( $60 \%$ after 3 days in culture). The other embryonic and two adult extracts exhibited significantly lower yet similar maximal survival effects (approximately $36 \%$ ), although the maximal effects of the soluble and matrix-bound adult extracts may have been reduced by the presence of toxic components in these extracts. The high maximal survival activity extractable from embryonic compared with adult skeletal muscle may reflect a greater reliance of devefoping embryonic motoneurons on trophic support during the period of naturally occurring motoneuron death or the production by adult muscle of a "neurotrophic cocktail" not optimally suited to the survival of embryonic neurons. Interestingly, high salt-EDTA extraction of embryonic and adult skeletal muscle af. forded extracts with apparent specific activities relative to total protein content that were approximately 4- and 17-fold greater, respectively, than their PBSsoluble counterparts. Thus, compared with soluble proteins, a larger proportion of matrix-bound proteins in muscle exhibit motoneuron survival activity.

Immunoprecipitation experiments with a specific antiserum to FGF-5 were used to ascertain what percentage, if any, of the motoneuron survival activity of the embryonic and adult muscle extracts might be attributable to FGF-5. From hindlimb skeletal muscle prepared from $\mathrm{E} 17$ rats, at which age the period of naturally occurring embryonic motoneuron death is underway (Oppenheim, 1986), approximately $60 \%$ of the total maximal extractable survival activity could be immunoprecipitated by the anti-FGF-5 antiserum. The FGF-5 immunoprecipitable activity in $\mathrm{E} 17$ muscle was distributed between a PBS-soluble form and a less readily extracted species, the latter requiring high molar salt and EDTA for extraction. In contrast, FGF-5 activity in adult skeletal muscle was found to exist exclusively in the latter, matrix-bound form. FGF-5, like the other members of the FGF family, exhibits strong binding to the glycosaminoglycan heparin (Zhan et al., 1988) and thus would be expected to associate tightly to heparan sulphate-like components of the extracellular matrix. Thus, the apparent lesser solubility of the FGF-5 immunoprecipitable activity from adult rat skeletal muscle compared with that of the embryo probably reflects a difference in the nature or composition of the extracellular matrix in the adult animal. Similar developmental changes have previously been noted in the case of extractability of other components of the extracellular matrix, such as laminin (Kücherer-Ehret et al., 1990).

An antiserum to a 27 amino acid peptide from CNTF (Stöckli et al., 1991) was favored over preimmune serum as a control serum for the immunoprecipitation experiments. The anti-CNTF antiserum was unable to precipitate the motoneuron survival activity of either recombinant FGF-5 or embryonic muscle extracts; the latter finding is in concordance with the observations that CNTF mRNA in the rat is below detectable limits during the period of naturally occurring motoneuron death (Stöckli et al., 1989, 1991). These results allowed us to disregard with confidence the interpretation that reductions in motoneuron survival activity observed following precipitation with the anti-FGF-5 antiserum might be due to nonspecific binding of a neurotrophic factor(s) to the generally increased IgG levels expected in immunized animals. A small yet significant reduction in the survival activity of adult muscle extracts could be brought about by immunoprecipitation with the anti-CNTF antiserum. This phenomenon is probably the result of the presence of CNTF in nerves innervating adult muscle. Indeed, CNTF immunoreactivity is clearly detectable in Schwann cells surrounding nerves in sections of adult skeletal muscle (B. Holtmann and $M$. Sendtner, unpublished data). Furthermore, extracts of adult rat skeletal muscle that has been surgically denervated for 7 days, during which time nerve fibers and their accompanying Schwann cells distal to the lesion site would be expected to degenerate, no longer exhibit anti-CNTF immunoprecipitable motoneuron survival activity (R. A. Hughes and M. Sendtner, unpublished data).

FGF-5 immunoprecipitable activity in E17 skeletal muscle extracts could originate from two sources, the muscle itself (as the observed expression of FCF-5 mRNA in this tissue would attest) and/or a site of earlier expression. Indeed, the most prominent embryonic expression of FGF- 5 mRNA beyond gastrulation in the mouse occurs at E12.5-E14.5 in a patch of mesenchyme at the base of the hindlimb (Haub and Goldfarb, 1991). It may be that FGF-5 protein similarly expressed in the developing rat is deposited in the surrounding muscle and thus contributes to the observed FGF-5-like activity in E17 muscle extracts. The expression of FGF-5 mRNA in adult rat muscle is consistent with the hypothesis that the major source of FGF- 5 in this tissue is the muscle itself. The previously reported absence of FGF-5 mRNA in Northern blots of RNA from aduit mouse skeletal muscle (Haub et al., 1990) suggests either that the FGF-5 gene is regulated differently in these two species, or that the amounts of FGF-5 mRNA in mouse were below detectable limits. Our investigations do not formally exclude the possibility that the FGF-5-like activity observed in skeletal muscle might be supplied in part by nerve fibers present within the muscle. However, the apparent contribution of CNTF to the survival activity of adult muscle extracts is small, indicating that the contamination of these extracts with nerve fibers is minor. Thus, unless sciatic nerve proves to be an exceptionally rich source of FGF-5, it is unlikely that the FGF-5like activity observed in muscle extracts is derived to a significant extent from nervous tissue.

A family of membrane-spanning protein tyrosine kinases, encoded by at least four distinct genes, are capable of acting as signal-transducing units for the FGFs (Ruta et al., 1988; Kornbluth et al., 1988; Lee et al., 1989; Dionne et al., 1990; Pasquale, 1990; Miki et 
al., 1991; Keegan et al., 1991; Partanen et al., 1991; Stark et al., 1991). These tyrosine kinases exist in a variety of molecular forms generated by alternative RNA splicing (Johnson et al., 1990, 1991) and bind different members of the FGF family with differing affinities (Johnson et al., 1991; Miki et al., 1991; Partanen et al., 1991). The binding of FGFs to the receptor tyrosine kinases requires the participation of heparan sulphate proteoglycan or soluble heparin (for review, see Klagsbrun and Baird, 1991). Recombinant human FGF-5 is able to bind and activate FGF receptors 1 and 2 . The relative affinities of FGF-5 and bFGF for these receptors (D. Clements, I.-K. Wang, C. Dionne, and M. Goldfarb, unpublished data) correlate with the relative concentrations of these factors required to support chick motoneurons in culture. This would suggest that the expression of FGF receptor 1 or 2 in embry. onic motoneurons partially accounts for FGF survival effects. Indeed, mRNA for FGF receptor 1 has been detected in motoneurons of newborn and adult rats using in situ hybridization techniques (Wanaka et al., $1990,1991)$. Given the enhanced survival of chick motoneurons cultured in the presence of a combination FGF-5 and bFGF, it is possible that at least three distinct FGF receptors mediate survival of chick motoneurons in vitro: one receptor with specificity for FGF-5, one for bFGF, and a third (perhaps FGF receptor 1 or 2 ) able to respond to both ligands.

The molecular nature of the motoneuron survival activity present in embryonic and adult skeletal muscle extracts that could not be immunoprecipitated by anti-FGF-5 antiserum remains undetermined. The presence of other FGF-related molecules in skeletal muscle of several species is relatively well documented even though the exact molecular entity under question has not always been precisely defined. Using immunohistochemical techniques, bFGF-like immunoreactivity has been detected in developing skeletal muscle of embryonic chick (Joseph-Silverstein et al., 1989), rat (Gonzalez et al., 1990), and rabbit (Morrow et al., 1990), and a molecule with bFGF-like characteristics has been detected in human embryonic and adult skeletal muscle (Vaca et al., 1989). In a similar manner, polyclonal antisera to aFGF have been used to demonstrate the presence of this molecule in embryonic rat skeletal muscle (Fu et al., 1991), and mRNA for aFGF has been detected by Northern blot analysis of total RNA obtained from embryonic cattle muscle (Alterio et al., 1990). Nonetheless, the absence of demonstrable secretion of aFGF and bFGF makes it difficult to reconcile how either of these factors might be made available to act as a target-derived neurotrophic factor for motoneurons.

A number of other candidate target-derived trophic factors for developing spinal motoneurons have previously been proposed. One of these, choline acetyltransferase development factor (CDF), has been purified from rat skeletal muscle and shown to increase levels of choline acetyltransferase activity in embryonic rat spinal cord cultures (McManaman et al., 1988,
1989). Although conclusive survival effects of CDF on highly enriched or purified motoneuron cultures have yet to be demonstrated, CDF does share a number of properties with FGF-5, including apparent abundance in skeletal muscle and effects that are additive with bFGF (McManaman et al., 1989; MCManaman and Crawford, 1991). Nonetheless, several differences between CDF and FGF-5, such as extent of glycosylation and heparin binding characteristics, suggest that they are distinct entities. Identification of the exact molecular nature of CDF awaits the cloning of this factor.

A cholinergic differentiation factor for sympathetic neurons originally isolated from heart muscle-conditioned medium (Fukada, 1985) was found upon cloning (Yamamori et al., 1989) to be identical to leukemia inhibitory factor (LIF). LIF exhibits a degree of functional overlap with CNTF (for review, see Patterson, 1992), including a survival effect on cultured rat motoneurons (Martinou et al., 1992). It has recently been reported that LIF mRNA, unlike CNTF message, is present in low amounts in embryonic rat skeletal muscle (Patterson and Fann, 1992). However, it has been shown that murine LIF is unable to act on other chick cells in culture even at high concentrations (Rohrer, 1992), presumably as a result of species differences. Thus, LIF would not be expected to contribute to the motoneuron survival activity of the rat muscle extracts observed in the cultures described here. The extent to which LIF produced in rat skeletal muscle might promote motoneuron survival and function remains a matter of conjecture.

The data presented here demonstrate that FGF-5 is a major skeletal muscle-derived survival factor for cultured spinal motoneurons. Furthermore, the expression of FGF.5 in muscle and its secretory nature are compatible with the hypothesis that this protein may provide target-derived trophic support to motoneurons both during embryonic development and in adulthood. Other experimental systems could be used to clarify whether FGF-5 indeed plays a role in regulating motoneuron survival in vivo, or perhaps partakes in the modulation of other motoneuronrelated functions, such as transmitter synthesis or synapse formation. These systems include the in vivo administration of blocking FGF-5 antibodies during development, and the gene knockout or tissue-specific overexpression of FGF-5 in transgenic animals.

\section{Experimental Procedures}

\section{Materials}

Recombinant human FGF-5 was purified from the soluble fraction of Escherichia colilysates by heparin-Sepharose chromatography and Mono $S$ fast protein liquid chromatography (D. Clements, I.-K. Wang, C. Dionne, and M. Goldfarb, submitted). Recombinant rat CNTF was prepared from transfected $E$. coli using a modification of the method described by Masiakowski et al. (1991), in which the chromatographic purification of the protein on DEAE-cellulose was replaced by a single reversephase, high pressure liquid chromatography step on a semipreparative, butyl column (Baker). Recombinant human K-FGF was 
generously provided by C. Basilico, NY. Recombinant afGF and bFGF were kind gifts from W. Risau, Martinsried, Germany. $\mathrm{N}$-ffuorenylmethoxycarbonyl (Fmoc) amino acid derivatives, 2-(7H-benzotriazol-1-yl)-1,1,3,3-tetramethyluronium hexafluorophospate (HBTU), HMP resin, solvents, and miscellaneous reagents for peptide synthesis were from Applied Biosystems, Weiterstadt, Germany; Freund's complete and incomplete adjuvants and Leibovitz's L-15 medium, from CIBCO BRL, Eggenstein, Germany; metrizamide, from Serva, Heidelberg, Germany; protein G-Sepharose solution, from Pharmacia, Freiburg, Cermany; general laboratory reagents, from Sigma Chemie, Deisenhofen, Germany, and E. Merck, Darmstadt, Germany.

\section{Northern Blots}

Hindlimb skeletal muscle was dissected from embryonic (E15 and $E 177$, newborn, and adult rats killed by ether overdose. Particular care was taken to exclude bone, cartilage, and skin, and total RNA was extracted from the muscle according to the method of Chomczynski and Sacchi (1987). RNA samples thus obtained were glyoxylated, electrophoresed through a $1.4 \%$ agarose gel (Lind holm et al., 1988), and vacuum blotted to nylon membranes (Hybond-N, Amersham, Braunschweig, Germany). The membranes were hybridized overnight in $50 \%$ formamide as de scribed (Castren et al., 1992) with a 500 bp cRNA probe to FCF-5. The probe (specific activity $10^{9} \mathrm{cpm} / \mu \mathrm{g}$ ) was made by run-on transcription of a pBluescript SK+ vector containing a $2.2 \mathrm{~kb}$ mouse Fgf-5 cDNA fragment (Haub and Goldfarb. 1991) linear. ized with BglII.

\section{Antiserum Preparation}

The nonadecapeptide CFKQSEQPELSFTVTVPEK containing a relatively hydrophilic 18 amino acid sequence from near the $C$-ter minus of human FCF-5 (Phe-217 to Lys-234), which is highly conserved between species (human-mouse amino acid identity of $100 \%$; Haub et al., 1990) but bears no sequence homology with other members of the FGF family, was synthesized on an Applied Biosystems 431A automated peptide synthesizer using N-Fmoc amino acid derivatives and HBTU-assisted coupling steps. Following deprotection and cleavage from the resin, the crude peptide free acid was purified as required by reverse-phase, high pressure liquid chromatography from $0.1 \%$ trifluoroacetic acid on a butyl column using an acetonitrile gradient $10 \%-70 \%$ acetonitrile in $30 \mathrm{~min}$ ). New Zealand rabbits were immunized by int $\mathrm{ra}$ cutaneous injection into at least four sites on the back with 700 $\mu \mathrm{g}$ of the above-described peptide dissolved in $500 \mu \mathrm{l}$ of $\mathrm{H}_{2} \mathrm{O}$ and emulsified with an equal volume of Freund's complete adjuvant. Rabbits were boosted with a similar quantiry of peptide solution emulsified with freund's incomplete adjuvant at 3-4 weekly intervals. Blood samples were removed 1 week after boosting by severing an ear vein, allowed to coagulate $\left(37^{\circ} \mathrm{C}\right.$ for $2 \mathrm{hr}$ then overnight at $\left.4^{\circ} \mathrm{C}\right)$, and centrifuged $(6000 \times \mathrm{g}, 25 \mathrm{~min})$. The resultant serum was sterile filtered $(0.2 \mu \mathrm{m})$ and used in immunoprecipitation assays.

\section{Motoneuron Cultures}

Chick spinal motoneuron cultures were prepared as previously described (Arakawa et at., 1990). Briefly, lateral motor columns were dissected from the lumbar region of six E6 chick spinal cords, trypsinized, and triturated. The resultant celt suspension was filtered and centrifuged through a bed of $6.8 \%$ metrizamide Cells from the interface were collected, and the suspension was concentrated by centrifugation, resuspended in $\mathrm{CO}_{2}$-buffered L-15 medium supplemented with horse serum (10\%), and plated in four well culture dishes (C. A. Greiner und Söhne $\mathrm{GmbH}$, Nürtingen, Germany) at a concentration of $1000-2000$ cells per well. The wells had been previously coated with poly-Dtornithine and laminin (the latter solu.i.un was removed just prior to plating). The cells were incubated at $37^{\circ} \mathrm{C}$ in a humidified incubator in an atmosphere of $5 \% \mathrm{CO}_{2}$ for $1 \mathrm{hr}$, factors and/or extracts were added at the appropriate concentrations, and cells were returned to the incubator for the length of the experiment. The culture medium and factors were renewed after $24 \mathrm{hr}$. Large $(\geqslant 14 \mu \mathrm{m}$ in diameter), phase-bright cells were counted $72 \mathrm{hr}$ after plating, unless otherwise specified, in predetermined areas corresponding to $23 \%$ of each well bottom.

\section{Preparation of Skeletal Muscle Extracts}

Hindlimb skeletal muscle was dissected from embryonic (E17) and adult rats as described above. Extracts of soluble skeletal muscle proteins were obtained by homogenizing the muscle on ice in 2-3 volumes of PBS in a glass-glass homogenizer and centrifuging $\left(100,000 \times \mathrm{g}, 4^{\circ} \mathrm{C}, 30 \mathrm{~min}\right)$. Matrix-bound components were obtained by reextraction of the pellets obtained above with 2-3 initial muscle volumes of PBS supplemented with $\mathrm{NaCl}(3 \mathrm{M})$ and EDTA $(10 \mathrm{mM})$ and centrifugation as for soluble extracts. The protein concentration of the resultant extracts was determined by the method of Bradford (1976) using bovine se rum albumin as a standard. The skeletal muscle extracts were stored at $-70^{\circ} \mathrm{C}$ until use.

\section{Immunoprecipitation Experiments}

Thirty microliters of protein G-Sepharose Fast Flow suspension was centrifuged $(14,000 \mathrm{rpm}, 5 \mathrm{~min})$, and the Sepharose was resuspended in $150 \mu$ l of $0.5 \times$ Tris-buffered saline $(\mathrm{pH} \mathrm{7.4)}$ ). To this suspension was added $200 \mu$ of either anti-FCF-5 peptide antiserum prepared as described above or control antiserum raised against a 27 amino acid peptide from CNTF (antiserum 1; Stöckli et al., 1991). The mixture was incubated for $1 \mathrm{hr}$ at room temperature on an inverting mixer. The protein G-Sepharose antiserum complex was washed three times with $500 \mu$ l of Trisbuffered saline, after which $20 \mu \mathrm{l}$ of $0.5 \times$ TBS and either $60 \mu \mathrm{l}$ of muscle extract $(5 \mu \mathrm{g} / \mu)$ ) or $60 \mu$ l of recombinant human FGF-5 solution $\left(1 \mathrm{ng} / \mathrm{h}\right.$ t in $\mathrm{L}-15\left(\mathrm{CO}_{2}\right)$ ) medium supplemented with $10 \%$ horse serum) were added. Following centrifugation. the resultant supernatants were added to motoneuron cultures.

\section{Acknowledgments}

We wish to thank Jen-Kuei Wang for the purification of recombinant FGF-5 and Dr. David Edgar for suggesting the use of EDTA to assist in the extraction of matrix-bound proteins. $R$. A. H. was the recipient of a postdoctoral fellowship from the Alexander von Humboldt-Stiftung.

The costs of publication of this article were defrayed in part by the payment of page charges. This article must therefore be hereby marked "advertisement" in accordance with 18 USC Section 1734 solely to indicate this fact.

Received August 21, 1992; revised December 15, 1992

\section{References}

Abraham, I. A., Mergia, A., Whang, J. L., Tumolo, A., Friedman, I., Hierrild, K. A., Gospodarowicz, D., and Fiddes, I. C. (1986) Nucleotide sequence of a bovine clone encoding the angiogenic protein, basic fibroblast growth factor. Science 233. 545-548.

Alterio, I., Courtois, Y., Robelin, 1., Bechet, D., and Martelly, I. (1990). Acidic and basic fibroblast growth factor mRNAs are expressed by skeletal muscle satellite cells. Biochem. Biophys. Res. Commun. 166. 1205-1212.

Arakawa, Y., Sendtner, M., and Thoenen, H. (1990). Survival effect of ciliary neurotrophic factor (CNTF) on chick embryonic motoneurons in culture: comparison with other neurotrophic factors and cytokines. J. Neurosci. 10, 3507-3515.

Barde, Y.-A. (1989). Trophic factors and neuronal survival. Neuron 2, 1525-1534.

Bates, B., Hardin, I., Zhan, X., Drickamer, K., and Coldfarb, M. (1991). Biosynthesis of human fibroblast growth factor-5. Mol. Ceil. Biol. 17, 1840-1845.

Bennet, M. R., Lai, K., and Nurcombe, V. (1980). Identification of embryonic motoneurons in vitro: their survival is dependent on skeletal muscle. Brain Res. 190, 537-542.

Bloch-Gallego, E., Huchet, M., El M'hamdi, H., Xie, F.-K., Tanaka, $H$, and Henderson, C. E. (1991). Survival in vitro of motoneurons 
identified or purified by novel antibody-based methods is selec tively enhanced by muscle-derived factors. Development 111 , 221-232.

Bradford, M. M. (1976). A rapid and sensitive method for the quantitation of microgram quantities of protein utilizing the principle of protein-dye binding. Anal. Biochem. $72,248-254$.

Calof, A. L., and Reichardt, L. F. (1984). Motoneurons purified by cell sorting respond to two distinct activities in myotubeconditioned medium. Dev. Biol. 106, 194-210.

Castrén, E., Zafra, F., Thoenen, H., and Lindholm, D. (1992). Light regulates the expression of brain-derived neurotrophic factor mRNA in rat visual cortex. Proc. Natl. Acad. Sci. USA, in press. Chomczynski, P., and Sacchi, N. (1987). Single-step method of RNA isolation by guanidinium thiocyanate-phenol-chloroform extraction. Anal. Biochem. 162, 156-159.

Dionne, C. A., Crumley, G., Bellot, F., Kaplow, I. M., Searfoss, G., Ruta, M., Burgess, W. H., Jaye, M., and Schlessinger, J. (1990). Cloning and expression of two distinct high-affinity receptors cross-reacting with acidic and basic fibroblast growth factors. EMBO ।. 9, 2685-2692.

Dohrmann, U., Edgar, D., Sendtner, M., and Thoenen, H. (1986). Muscle-derived factors that support survival and promote fiber outgrowth from embryonic chick spinal motor neurons in culture. Dev. Biol. 178, 209-221.

Flanigan, T. P., Dickṣon, J. G., and Walsh, F.S. (1985). Cell survival characteristics and choline acetyltransferase activity in motor neurone-enriched cultures from chick embryo spinal cord. I Neurochem. 45, 1323-1326.

Fu, Y.-M., Spirito, P., Yu, Z.-X., Biro, S., Sasse, J., Lei, J., Ferrans V. J., Epstein. S. E., and Casscells, W. (1991). Acidic fibroblast growth factor in the developing rat embryo. 1. Cell Biol. 114, 1261-1273.

Fukada, K. (1985). Purification and partial characterization of a cholinergic neuronal differentiation factor. Proc. Natl. Acad. Sci. USA 82, 8795-8799.

Gonzalez, A.-M., Buscaglia, M., Ong, M., and Baird, A. (1990). Distribution of basic fibroblast growth factor in the 18-day rat fetus: localization in the basement membranes of diverse tissues. 1. Cell Biol. 110, 753-765.

Hamburger, V. (1958). Regression versus peripheral control of differentiation in motor hyperplasia. Am. J. Anat. 102, 365-410. Haub, O., and Coldfarb, M. (1991). Expression of the fibroblast growth factor-5 gene in the mouse embryo. Development 112 , $397-406$.

Haub, O., Drucker, B., and Goldfarb, M. (1990). Expression of the murine fibroblast growth factor 5 gene in the adult central nervous system. Proc. Natl. Acad. Sci. USA 87, 8022-8026.

Hébert, J. M., Basilico, C., Goldfarb, M., Haub, O., and Martin, G. R. (1990). Isolation of CDNAs encoding four mouse FGF family members and characterization of their expression patterns during embryogenesis. Dev. Biol. 138, 454-463.

Hébert, J. M., Boyle, M., and Martin, G. R. (1991). MRNA localization studies suggest that murine FGF-5 plays a role in gastrulation. Development 112, 407-415.

Hollyday, M., and Hamburget, V. (1976). Reduction of the naturally occurring motor neuron loss by enlargement of the periphery. J. Comp. Neurol. 170, 311-320.

Hopp, T. P., and Woods, K. R. (1981). Prediction of protein antigenic determinants from amino acid sequences. Proc. Natt. Acad. Sci. USA 78, 3824-3828.

Jeong, S. J., Oh, T. H., and Markelonis, G. J. (1991). A neuritepromoting factor from muscle supports the survival of cultured chicken spinal motor neurons. J. Neurobiol. 22, 462-474.

Johnson, D. E., Lee, P. L., Lu, J., and Williams, L. T. (1990). Diverse forms of a receptor for acidic and basic fibroblast growth factors. Mol. Cell. Biol. 10, 4728-4736.

Johnson, D. E., LU, J., Chen, J., Werner, S., and Williams, L. T. (1991). The human fibroblast growth factor receptor genes: a common structural arrangement underlies the mechanisms for generating receptor forms that differ in their third immunoglobulin domains. Mol. Cell. Biol. 11, 4627-4634.

Joseph-Silverstein, J., Consigli, S. A., Lyser, K. M., and Ver Pault, C. (1989). Basic fibroblast growth factor in the chick embryo: immunolocalization to striated muscle cells and their precursors. J. Cell Biol. 108, 2459-2466.

Kaufman, L. M., Barry, S. R., and Barrett, J. N. (1985). Characterization of tissue-derived macromolecules affecting transmitter synthesis in rat spinal cord neurons. J. Neurosci. 5, 160-166.

Keegan, K., Johnson, D. E., Williams, L. T., and Hayman, M. J. (1991). Isolation of an additional member of the fibroblast growth factor receptor family, FGFR-3. Proc. Natl. Acad. Sci. USA 88, 1095-1099.

Klagsbrun, M., and Baird, A. (1991). A dual receptor system is required for basic fibroblast growth factor activity. Cell 67, 229 . 231.

Kornbluth, S., Pautson, K. E., and Hanafusa, H. (1988). Novel tyrosine kinase identified by phosphotyrosine antibody screening of cDNA libraries. Mol. Cell. Biol. 8, 5541-5544.

Kücherer-Ehret, A., Pottgiesser, J., Kreutzberg, G. W., Thoenen, H., and Edgar, D. (1990). Developmental loss of laminin from the interstitial extracellular matrix correlates with decreased laminin gene expression. Development 170, 1285-1293.

Kyte, J., and Doolittle, R. F. (1982). A simple method for displaying the hydropathic character of a protein. J. Mol. Biol. 157, 105-132.

Lee, P. L., Johnson, D. E., Cousens, L. S., Fried, V. A., and Williams, L. T. (1989). Purification and complementary DNA cloning of a receptor for basic fibroblast growth factor. Science 245, 57-60.

Lin, L.-F. H., Mismer, D., Lile, J. D., Armes, L. G., Butler, E. T., Ill, Vannice, J. L., and Collins, F. (1989). Purification, cloning, and expression of ciliary neurotrophic factor (CNTF). Science 246, 1023-1025.

Lindholm, D, Heumann, R., Hengerer, B., and Thoenen, $H$. (1988). Interleukin 1 increases stability and transcription of mRNA encoding nerve growth factor in cultured rat fibroblasts. J. Biol. Chem. 263, 16348-16351.

Martinou, J. C., Le Van Thai, A., Cassar, G., Roubinet, F., and Weber, M. J. (1989). Characterization of two factors enhancing choline acetyltransferase activity in cultures of purified rat motoneurons. J. Neurosci. 9, 3645-3656.

Martinou, J.-C., Martinou, I., and Kato, A. C. (1992). Cholinergic differentiation factor (CDF/LIF) promotes survival of isolated rat embryonic motoneurons in vitro. Neuron 8, 737-744.

Masiakowski, P., Liu, H., Radziejewski, C., Lottspeich, F., Oberthuer, W., Wong, V., Lindsay, R. M., Furth, M. E., and Panayotatos, N. (1991). Recombinant human and rat ciliary neurotrophic factors. J. Neurochem. 57, 1003-1012.

McManaman, J. L., and Crawford, F. C. (1991). Skeletal muscle proteins stimulate cholinergic differentiation of human neuroblastoma cells. I. Neurochem. 57, 258-266.

McManaman, J., Crawford, F., Clark, R., Richker, J., and Fuller, F. (1989). Multiple neurotrophic factors from skeletal muscle: demonstration of effects of basic fibroblast growth factor and comparisons with the 22-kilodalton choline acetyltransferase development factor. J. Neurochem. 53, 1763-1771.

McManaman, J. L., Crawford, F. G., Stewart, S. S., and Appel, S. H. (1988). Purification of a skeletal muscle polypeptide which stimulates choline acetyltransferase activity in cultured spinal cord neurons. J. Biol. Chem. 263, 5890-5897.

Miki, T., Fleming, T. P., Bottaro, D. P., Rubin, I. S., Ron, D., and Aaronson, S. A. (1991). Expression CDNA cloning of the KCF receptor by creation of a transforming autocrine loop. Science 251 , 72-75.

Morrow, N. G., Kraus, W. E., Moore, J. W., Williams, R. S., and Swain, J. L. (1990). Increased expression of fibroblast growth factors in a rabbit skeletal muscle model of exercise conditioning. J. Clin. Invest. 85, 1816-1820. 
O'Brien, R. J., and Fischbach, C. D. (1986). Isolation of embryonic chick motoneurons and their survival in vitro. 1. Neurosci. 6, 3265-3274.

Oppenheim, R. W. (1986). The absence of significant postnatal motoneuron death in the brachial and lumbar spinal cord of the rat. ). Comp. Neurol. 246, 281-286.

Oppenheim, R. W. (1991). Cell death during development of the nervous system. Annu. Rev. Neurosci. 14, 453-501.

Oppenheim, R. W., Prevette, D., Qin-Wei, Y., Collins, F., and MacDonald, J. (1991). Control of embryonic motoneuron survival in vivo by ciliary neurotrophic factor. Science 251, 1616-1618.

Partanen, J., Mäkelan̈, T. P., Eerola, E., Korhonen, J., Hirvonen, H., Claesson-Welsh, L., and Alitalo, K. (1991). FGFR-4, a novel acidic fibroblast growth factor receptor with a distinct expression pattern. EMBO J. 10, 1347-1354.

Pasquale, E. B. (1990). A distinctive family of embryonic proteintyrosine kinase receptors. Proc. Natl. Acad. Sci. USA 87, 58125816.

Patterson, P. H. (1992). The emerging neuropoietic cytokine family: first CDF/IF, CNTF and IL-6; next ONC, MGF, GCSF? Curr. Opin. Neurobiol. 2, 94-97.

Patterson, P. H., and Fann, M.-J. (1992). Further studies of the distribution of CDF/LIF mRNA. Ciba Found. Symp. 767, 125-135. Rohrer, H. (1992). Cholinergic neuronal differentiation factors: evidence for the presence of both CNTF-like and non-CNTF-like factors in developing rat footpad. Development 114, 689-698.

Ruta, R., Howk, R., Ricca, G., Drohan, W., Zabelshansky, M., Laureys, G., Barton, D. E., Francke, U., Schlessinger, J, and Givol, D. (1988). A novel protein tyrosine kinase gene whose expression is modulated during endothelial cell differentiation. Oncogene 3, 9-15.

Schnaar, R. L., and Schaffner, A. E. (1981). Separation of cell types from embryonic chicken and rat spinal cord: characterization of motoneuron enriched fractions. I. Neurosci. 1, 204-217.

Sendtner, M., Kreutzberg, C.W., and Thoenen, H. (1990). Ciliary neurotrophic factor prevents the degeneration of motor neurons after axotomy. Nature 345, 440-441.

Smith, R. G., McManaman, 1., and Appel, S. H. (1985). Trophic effects of skeletal muscle extracts on ventral spinal cord neurons in vitro: separation of a protein with morphologic activity from proteins with cholinergic activity. J. Cell Biol. 101, 1608-1621.

Stark, K. L., MCMahon, J. A., and MCMahon, A. P. (1991). FGFR-4, a new member of the fibroblast growth factor receptor family, expressed in the definitive endoderm and skeletal muscle lineages of the mouse. Development 113, 641-651.

Stöckli, K. A., Lottspeich, F., Sendtner, M., Masiakowski, P., Carroll, P., Götz, R., Lindholm, D., and Thoenen, H. (1989). Molecular cloning, expression and regional distribution of rat ciliary neurotrophic factor. Nature 342, 920-923.

Stöckli, K. A., Lillien, L. E., Näher-Noé, M., Breitfeld, G., Hughes, R. A., Raff, M. C., Thoenen, H., and Sendtner, M. (1991). Regional distribution, developmental changes, and cellular localization of CNTF-mRNA and protein in the rat brain. ). Cell Biol. 115, 447459.

Vaca, K., Stewart, S. S., and Appel, S. H. (1989). Identification of basic fibroblast growth factor as a cholinergic growth factor from human muscle. J. Neurosci. Res. 23, 55-63.

Wanaka, A., Johnson, E. M., Jr., and Milbrandt, J. (1990). Localization of FGF receptor mRNA in the adult rat central nervous system by in situ hybridization. Neuron 5, 267-281.

Wanaka, A., Milbrandt, J., and Johnson, E. M., Jr. (1991). Expression of FGF receptor gene in rat development. Development 111 , 455-468.

Werner, S., Roth, W. K., Bates, B., Goldfarb, M., and Hofschneider, P. H. (1991). Fibroblast growth factor 5 proto-oncogene is expressed in normal human fibroblasts and induced by serum growth factors. Oncogene 6, 2137-2144.

Yamamori, T., Fukada, K., Aebersold, R., Korsching, S., Fann,
M.-J., and Patterson, P. H. (1989). The cholinergic neuronal differentiation factor from heart cells is identical to leukemia inhibitory factor. Science 246, 1412-1416.

Zhan, X., Culpepper, A., Reddy, M., Loveless, I., and Goldfarb, $M$. (1987). Human oncogenes detected by a defined medium culture assay. Oncogene 1, 369-376.

Zhan, X., Bates, B., Hu, X., and Goldfarb, M. (1988). The human FGF-5 oncogene encodes a novel protein related to fibroblast growth factors. Mol. Cell. Biol. 8, 3487-3495. 